Actualization of Islamic Religious Education Values in the Life of Students at the NW Al-Akhyar Ibtidakiyah Madrasah Bagik Polak Barat Labuapi District West Lombok Regency West Nusa Tenggara Province 2019-2020 Academic Year

\title{
Aktualisasi Nilai-nilai Pendidikan Agama Islam Dalam Kehidupan Santri di Madrasah Ibtidakiyah NW Al-Akhyar Bagik Polak Barat Kecamatan Labuapi Kabupaten Lombok Barat Provinsi Nusa Tenggara Barat Tahun Pelajaran 2019-2020
}

\section{Mastur}

email: mastur1234@gmail.com

\begin{abstract}
Dosen Tetap STIT Darussalimin NW Sengkol Mantang Batukliang Praya Lombok Tengah
\end{abstract}

\begin{abstract}
Education is a shared responsibility between family, community and school (government). The 1998 GBHN states that education is life-long and is carried out in the family, school and community environment, therefore education is a shared responsibility between family, community and government. In the case of religious education, in general it is a shared responsibility, especially for families, communities and schools or madrasahs. In collecting data in this journal, using the following methods: Observation Methods, Library Methods and Documentary Methods. In this regard, we can draw conclusions 1. Religious education plays an important role in our lives and lives and is an effort that must be carried out for students because religious ideals have a higher and wider value than others. Religion concerns matters of belief or faith which require accuracy and persistence and we must really understand how to present it to students so that the desired goals can be achieved properly. 2 . The duties and responsibilities of parents as educators have a very big influence on students. Because the parents in the family / household are the first to be recognized by the child. 3 . Children are beings who are developing towards perfection (adult). Step by step the child's development is the development of the mental functions of the child as a whole. Each connected with the other at each level of development requires guidance and leadership. So this is where the role and function of parents in providing guidance and education to children. 4. The aim of religious education is to prepare children so that one day it is enough to do jobs that make themselves happy according to the norms and rules of the Islamic religion. Creating children so that they can be devoted to their parents, know and practice the teachings of their religion, both those related to their personality, society and those directly related to their god. 5 . The condition of the teacher and the development
\end{abstract}

$$
\text { 49| Edisiz No.2 Juli } 2020
$$


of his students is quite advanced and is developing in accordance with the era of development, especially in the fields of education and culture.

Keywords: Educational Values, Islamic Religious Education, Student Life

\begin{abstract}
Abstrak: Pendidikan merupakan tanggung jawab bersama antara keluarga, masyarakat dan sekolah (pemerintah). Dalam GBHN 1998 mengatakan pendidikan seumumr hidup dan dilaksanakan dalam lingkungan keluarga, sekolah dan masyarakat karena itu pendidikan adalah merupakan tanggungjawab bersama antara keluarga, masyarakat dan pemerintah. Dalam masalah pendidikan agama, secara umum adalah tanggungjawab bersama, terutama bagi keluarga, masyarakat dan sekolah atau Madrasah. Di dalam pengumpulan data pada jurnal ini, menggunakan metode-metode sebagai berikut: Metode Observasi, Metode Kepustakaan dan Metode Dokumenter. Sehubungan dengan hal tersebut maka dapat mengambil kesimpulan 1. Pendidikan agama memegang peranan penting dalam hidup dan kehidupan kita dan merupakan suatu usaha yang harus dijalankan kepada anak didik karena cita-cita keagamaan itu mempunyai nilai yang lebih tinggi dan lebih luas dari yang lainnya. Agama itu menyangkut masalah keyakinan atau iman yang membutuhkan kecermatan dan ketekunan serta kita harus mengerti benar-benar bagaimana menyajikannya terhadap anak didik agar tujuan yang diinginkan dapat di capai dengan baik. 2. Tugas dan tanggung jawab orang tua sebagai pendidik sangat besar pengaruhnya terhadap anak didik. Sebab orang tua dalam keluarga/rumah tangga adalah orang yang pertama dikenal oleh anak. 3. Anak adalah makhluk yang sedang berkembang menuju ke arah kesempurnaan (dewasa). Setingkat demi setingkat perkembangan anak adalah perkembangan fungsi-fungsi jiwa anak secara keseluruhan. Masing-masing berhubungan dengan yang lainnya pada masing-masing tingkat perkembangan itu memerlukan bimbingan dan pimpinan. Maka disinilah peran dan fungsi orang tua dalam memberikan bimbingan dan pendidikan kepada anak. 4. Tujuan pendidikan agama adalah menyiapkan anak-anak supaya kelak cukup melakukan pekerjaan yang membahagaiakan dirinya sesuai dengan norma dan aturan-aturan agama Islam. Menciptakan anak agar dapat berbakti pada orang tuanya, mengetahui dan mengamalkan ajaraajaran agamanya, baik yang berhubungan dengan pribadinya, masyarakatnya maupun yang langsung berhubungan dengan tuhannya. 5. Keadaan guru dan perkembangan muridnya cukup maju dan berkembang sesuai dengan era pembangunan khususnya di bidang pendidikan dan kebudayaan.
\end{abstract}

Kata Kunci: Nilai-nilai Pendidikan, Pendidikan Agama Islam, Kehidupan Santri 


\section{A. Pendahuluan}

Pendidikan Agam Islam sesungguhnya merupakan suatu rangkaian kegiatan proses pergaulan yang edukatif yang meliputi pendidik, anak didik, alat pendidikan, tujuan dan lingkungan pendidikan, usaha yang digunakan untuk bimbingan sesuai dengan ajaran agama islam.

Untuk lebih jelasnya pengertian Pendidikan Agama Islam adalah sebagai berikut Pendidikan Agama Islam adalah segala usaha ynag berupa pengajaran, bimbingan dan asuhan terhadap anak agarkelak setelah selesai pendidikannya dapat memahami, menghayati, mengamalkan ajaran agamanya sebagai way of live (jalan kehidupan) sehari-hari, baik dalam kehidupan pribadi maupun social kemasyarakatan, (Departemen Pendidikan RI Pendidikan Agama Islam SMTA, Dirjen Bimbaga Islam, 1995/1996:9).

Kaitan dengan hal tersebut di atas, Zakiah Darajat, (1994:86) menjelaskan bahwa Pendidikan Agama Islam adalah usaha berupa bimbingan dan asuhan terhadap anak didik agar kelak setelah selesai pendidikannya dapat memahami dan mengamalkan ajaran Agama Islam serta dapat menjadikannya sebagai pandangan hidup (way of live).

Pendidikan merupakan tanggungjawab bersama antara keluarga, masyarakat dan sekolah (pemerintah). Dalam GBHN 1998 mengatakan pendidikan seumumr hidup dan dilaksanakan dalam lingkungan keluarga, sekolah dan masyarakatkarena itu pendidikan adalah merupakan tanggung jawab bersama antara keluarga, masyarakat dan pemerintah, (GBHN, 1988:48).

Dalam masalah pendidikan agama, secara umum adalah tanggungjawab bersama, terutama bagi keluarga, masyarakat dan sekolah. Dimana hal itu telah tertuang didalam undang-undang $1945 \mathrm{Bab} 111$ pasal 31 tentang pendidikan yang berbunyi: Tiap-tiap warga Negara berhak mendapat pendidikan dan pengajaran. Pemerintah mengusahakan dan menyelenggarakan system pengajaran nasional yang diatur dalam Undang-Undang Dasar 1945.

Adapun penulis memilih dan menetapkan judul jurnal ini disebabkan adanyan beberapa pertimbangan antara lain:

1) Pendidikan Agama bagi anak adalah sangat penting, karena itulah penulis merasa tertarik untuk membahasnya dengan mengambil obyek di Madrasah Ibtidakiyah NW Al-Akhyar Bagik Polak Barat Kecamatan Labuapi Kabupaten Lombok Barat Tahun Pelajaran 2019-2020.

2) Karena pendidikan sangat penting untuk diajarkan atau ditanamkan terutama kepada anak didik (generasi) yang masil dalam perkembangannya, sebab hal ini sangat besar pengaryhnya terhadap perkembangan jiwa dan kehidupanny, sehingga kelak mereka diharapkan dapat menjadi manusia yang berguna bagi agamanya, sekaligus dapat membahagiakannya lahir dan bathin, dunia akhirat.

3) Penulis mengambil obyek pada Madrasah Ibtidakiyah NW Al-Akhyar Bagik Polak Barat Kecamatan Labuapi Kabupaten Lombok Barat disebabkan peranannya sebagaimana pendidikan agama bagi anak besarsekali pengaruhnya didalam memberikan bimbingan dan didikan serta menanamkan pendidikan agama bagi anak didik terutama bagi anak.

$$
\text { 51|Edisiz No.2 Juli } 2020
$$


4) Penulis adalah salah seorang tenaga pengajar di Madrasah Ibtidakiyah NW AlAkhyar Bagik Polak Barat Kecamatan Labuapi Kabupaten Lombok Barat tersebut merasa berkewajiban untuk turut serta menyumbang darma bhaktibaik berupa tenaga maupun pikiran, dalam usaha meningkatkan perannya sebagai wadah pendidikan agama bagi anak.

\section{Pengertian Pendidikan Agama}

Yang dimaksud dengan pendidikan agama disini adalah Pendidikan Agama Islam. Pengertian pendidikan secara terminologi mengandung pengertian yang luas, namun untuk mendekatkan diri kepada istilah tersebut akan diketengahkan definisi yang telah ditetapkan oleh para ahli. Tetapi kita maklumi bahwa sarjana pendidikan memberikan definisi yang berbeda-beda tetapi sesungguhnya semua definisi tersebut mempunyai kandungan dan arti yang sama. Untuk mendapatkan definisi pendidikan ini penulis mengetengahkan pendapat para ahli sebagai berikut:

1. Djaka menjelaskan bahwa pendidikan adalah sekalian usaha orang dewasa dalam pergaulannya dengan anak-anak berupa bimbingan dalam perkembangan jasmani dan rohaninya yang mempunyai tujuan supaya anak didik kelak sanggup menyelenggarakan tugas hidupnya sebagai individu dan anggota masyarakat, (Djaka, 1999:6)

2. H.E. Syaifudin Anshori menegaskan: Pendidikan pada umumnya berarti Daya upaya memajukan budi pekerti (kekuatan batin), pikiran (int/e) dan jasmani anak. Maksudnya supaya dapat memajukan kesempurnaan hidup yakni kehidupan yang selaras dengan alamnya dan masyarakatnya, (1996:28)

Sehubungan dengan pengertian pendidikan tersebut mengandung unsurunsur sebagai berikut:

a. Usaha (kegiatan) itu besifat bimbingan (pimpinan atau pertolongan) dan dilakukan secara sadar

b. Ada pendidik, pembimbing atau penolong

c. Ada yang dididik atau siterdidik

d. Bimbingan itu mempunyai dasar dan tujuan

e. Dalam usaha itu selalu ada alat yang dipergunakan

3. Drs. Ahmad D. Marimba mengatakan bahwa: Pendidikan adalah bimbingan atau pimpinan secara sadar oleh si pendidik terhadap perkembangan jasmani dan rohani si terdidik, (1994:20).

4. Djumhur \& Drs. Moh. Surya mengatakan: Pada umumnya pendidikan dapat diartikan sebagai suatu proses bantuan yang diberikan oleh orang dewasa kepada anak yang belum dewasa untuk mencapai kedewasaan.

Berdasarkan keterangan di atas maka dapatlah penulis menarik kesimpulan bahwa pendidikan adalah suatu usaha bimbingan dan pimpinan yang dilakukan oleh orang dewasa (pendidik) terhadap anak (siterdidik) guna mengembangkan fitrah kemanusiaan agar anak didik menjadi dewasa jasmani dan rohaninya serta bertanggung jawab terhadap dirinya sendiri.

Sesuai dengan topik sub bab ini maka selanjutnya akan penulis kemukakan pengertian pendidikan agama islam guna mendapatkan kesimpulan dalam hal ini. Sebagaimana halnya dengan definisi (pengertian) pendidikan tersebut di atas

$$
\text { 52| Edisiz No.2 Juli } 2020
$$


maka definisi pendidikan agamapun akan penulis ketengahkan berdasarkan penjelasan para ahli ilmu pengetahuan. Berikut penulis paparkan pendapat para ahli tentang pengertian pendidikan agama:

1. Zuhairini, dkk menjelaskan: Pendidikan agama berarti usaha-usaha secara sitematis dan pragmatis dalam membantu anak didik agar supaya mereka hidup sesuai dengan pembelajaran Islam, (1990:3)

2. Drs. Ahmad D. Marimba menerangkan: Pendidikan agama adalah bimbingan jasmani dan rohani berdasarkan hukum-hukum agama islam menuju kepada terbentuknya kepribadian utama menurut ukuran-ukuran Islam, (1994:26).

Dari uraian-uraian di atas dapat dipahami bahwa pendidikan agama suatu bimbingan dan pimpinan jasmani dan rohani berdasarkan hukum-hukum dan ajaran islam menuju kearah terbentuknya keperibadian muslim yang sejati. Dengan demikian maka jelaslah bahwa apa yang terkandung dalam materi pendidikan agama adalah betul-betul merupakan perbuatan dan usaha yang sangat baik dan suci yang dengan secara sadar diberikan oleh orang dewasa (pendidik) dalam pergaulan yang khusus dengan anak-anak (siterdidik) untuk membimbing dan menuntun umat manusia agar selalu taat, patuh dan mengabdi kepada Tuhan Yang Maha Esa serta berbudi pekerti yang luhur berdasarkan norma-norma agama islam, seningga ia dapat menjalankan tugas dan tanggung jawabnya sebagai individu dan anggota masyarakat.

Bila kita perhatikan pengertian di atas secara baik dan cermat, maka dapatlah di mengerti bahwa pendidikan agama mengandung usur-unsur bimbingan dan tuntunan terhadap perkembangan jasmani dan rohani anak didik, sehingga anak didik akan menyadari sendiri tugas dan kewajiban sebagai manusia yang harus berbakti kepada Allah SWT menurut ajaran agama.

\section{Dasar dan Tujuan Pendidikan Agama}

\section{Dasar Pendidikan Agama}

Sebagaimana dimaklumi bahwa setiap bangunan tentu memiliki dasar (fundamen) sebagai tempat berdirinya dengan kokoh. Dan dasar ini merupakan bagian yang penting dari bangunan tersebut. Bila bangunan ini diibaratkan pohon kayu, maka kekuatannya tergantung pada dasarnya, artinya bila suatu bangunan atau pohon kayu berdiri di atas dasar atau akar yang kuat, maka dengan sendirinya bangunan atau pohon kayu tersebut akan berdiri dengan kuat, tegak dan kokoh serta tahan lama walaupun banyak rintangan dan cobaan yang menimpanya. Demikian pula halnya dengan pendidikan agama Islam tidak lepas dari dasar sebagai pedoman pelaksanaannya. Jadi dasar yang dimaksud disini adalah dasar atau pundamen yang merupakan pedoman pelaksanaan dalam mengarahkan, mengisi dan menentukan jalan yang harus ditempuh oelh pendidikan agama Islam dalam usaha mencapai tujuan. Dengan kata lain yang dimaksud dengan dasar pendidikan Islam disini adalah pangkal bertolaknya suatu usaha yang harus dijadikan pedoman dan dasar dalam pelaksanaan pendidikan agama Islam.

Pendidikan agama Islam mempunyai dasar serta standar yang kuat yang harus menjadi pegangan para pendidik agama islam. Dalam melaksanakan tugasnya dimana usaha atau kegiatan islam tidak boleh bertentangan dengan dasarnya yaitu al-Qur'an dan Hadits. Lebih lanjut diketengahkan bahwa dasar-

$$
\text { 53|Edisiz No.2 Juli } 2020
$$


dasar yang dijadikan pedoman atau pegangan dalam pelaksanaan pendidikan Islam tidak boleh bertentangan dengan:

\section{a. Dasar Religius}

Pendidikan agama Islam dilaksanakan atas dasar religius, maksudnya yaitu dasar yang bersumber dari al-Qur'an dan al-Hadits dimana keduanya merupakan pegangan pokok serta petunjuk bagi umat Islam dalam melaksanakan ajaran agamanya. Firman Allah dalam surat Al-Baqarah ayat 2:2 adalah:

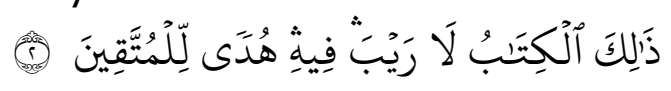

Artinya:

Kitab (Al Quran) Ini tidak ada keraguan padanya; petunjuk bagi mereka yang bertaqwa. (Al-Baqarah, 2:2).

Ayat-ayat tersebut di atas menegaskan bahwa al-Qur'an dan Sunnah Rasul (Hadits) adalah merupakan dasar yang fundamental bagi umat islam untuk berbuat bila dasar ini dipegang teguh dan dipedomani dengan penuh tanggung jawab, maka kekuatan dan keteguhan berdirinya pendidikan Islam tidak akan dapat digoyangkan oelh apapun, karena al-Qur'an dan Hadits adalah sumber kebenaran yang tidak dapat diragukan lagi. Oleh karena itu sebagai pendidik agama harus berpedoman dan berkeyakinan yang teguh terhadap kedua dasar tersebut.

Adapun ayat-ayat yang dijadikan dasar atau pegangan dalam melaksanakan Pendidikan Agama Islam antara lain sebagai berikut: Firman Allah SWT.dalam Surat Ali'Imran ayat 110:

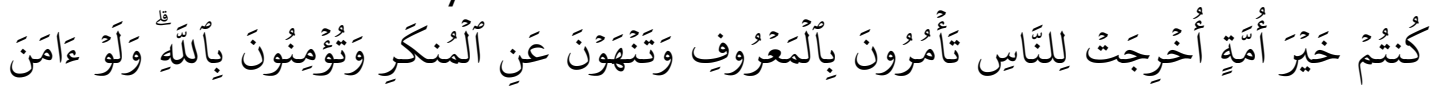

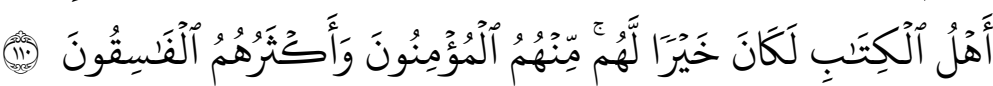

Artinya:

Kamu adalah umat yang terbaik yang dilahirkan untuk manusia, menyuruh kepada yang ma'ruf, dan mencegah dari yang munkar, dan beriman kepada Allah. sekiranya ahli Kitab beriman, tentulah itu lebih baik bagi mereka, di antara mereka ada yang beriman, dan kebanyakan mereka adalah orang-orang yang fasik. (Ali'Imran, 003:110).

Demikian sebagian ayat al-Qur'an dan Hadist Rasul sebagai pedoman pelaksanaan pendidikan agama yang harus dipegang teguh oleh para pendidik.

\section{b. Dasar Yuridis/Hukum}

Dasar yuridis maksudnya yaitu dasar hukum dalam pelaksanaan pendidikan agama berasal dari peraturan dan perundang-undangan yang berlau di negara RI, dimana dasar hukum ini dapat dibedakan atas:

\section{a) Dasar Ideal}

Yang dimaksud dengan dasar-dasar ideal disini adalah pancasila sebagai falsafah yang menjadi dasar pelaksanaan pendidikan dan pengajaran di negara RI. Hal ini sesuai dengan Undnag-Undang Pendidikan nomor 4 Tahun 1950 Bab III pasal 4 yang berbunyi "Pendidikan dan pengajaran berdasarkan asas-asas

$$
\text { 54|Edisiz No.2 Juli } 2020
$$


termaktub dalam pancasila, undang-undang dasar Negara RI dan atas kebudayaan bangsa indonesia. (Djaka, Rangkuman Ilmu Pendidikan, 14).

Jadi dengan demikian jelaslah dasar pendidikan dan pengajaran di indonesia harus sesuai dengan asas-asas termaktub dalam pancasila, dimana urutan sila dari pancasila tersebut dapat kita lihat pada alenia keempat Pembukaan Undang-Undang Dasar 1945 yang berbunyi sebagai berikut: Dengan berdasarkan kepada Tuhan Yang Maha Esa kemanusiaan yang adil dan beradab, Persatuan indonesia dan kerakyatan yang dipimpin oleh hikmat dan kebijaksanaan dalam permusyawaratan/perwakilan, serta dengan mewujudkan suatu keadilan sosial bagi seluruh rakyat indonesia (UUD 1945, P4, dan GBHN, 1993:3).

\section{b) Dasar Struktural}

Dasar struktural adalah dasar yang diambil dari undang-undang Dasar 1945, dimana pada Bab XI ini pada pasal 29 ayat 1 dan 2 berbunyi:

a) Negara berdasar atas Ketuhanan Yang Maha Esa

b) Negara menjamin kemerdekaan tiap-tiap penduduk untuk memeluk agamanya masing-masing dan beribadah menurut agama dan kepercayaan, (UUD 1945, P4, GBHN, 1993:12)

Memperhatikan bunyi dari UUD tersebut di atas, maka dapat dipahami bahwa negara memberikan hak dan kebebasan atau memberikan perlindungan kepada umatberagama untuk melaksanakan ajaran-ajarannya sesuai dengan kepercayaan masing-masing. Dalam hal ini penduduk indonesia yang mayoritas memeluk agana islam telah mendapatkan hak untuk mengembangkan ajaran agamanya kepada generasi mudanya melaui pendidikan agama sehingga dengan demikian mereka akan menghayati dan mengamalkan ajaran-ajaran agamanya sesuai bdengan hukum-hukum yang telah digariskan dalam islam.

Demikian juga dengan Keputusan bersama menteri pendidikan dan kebudayaan dengan menteri RI. No.0198/U/1985 Bab 2 pasal 2 ditegaskan tentang pelaksanaan pendidikan agama disekolah sekolah khususnya di lingkungan Direktorat Departemen Pendidikan dan Kebudayaan yang berbunyi sebagai berikut:

1) Pada sekolah-sekolah khusus di lingkungan Direktorat Jendral pendidikan dan kebudayaan wajib diberikan pendidikan agama paling kurang 2 jam pelajaran seminggu pada stiap kelas.

2) Setiap murid atau siswa wajib mengikuti pendidikan agama sesuai dengan yang dipercayai.

3) Setiap siswa/i penganut aliran dan kepercayaan wajib mengikuti agama yang dipikhnya, (Kementrian Agama RI:238).

Demikian pula pada UU RI No.2 Th.1989 tentang sistem pendidikan nasional dan penjelasannya pada Bab IV pasal 2 tentang satuan jalur dan jenis pendidikan telah ditetapkan bahwa jenis pendidikan, termasuk jalur pendidikan sekolah terdiri atas pendidikan umum, pendidikan kejuruan, pendidikan luar biasa, pendidikan kedewasaan, pendidikan akademik dan pendidikan profesional. (Menteri Pendidikan dan Kebudayaan). Kemudian pada ayat 6 lebih jelas lagi bahwa pendidikan keguruan merupaka pendidikan yang mempersiapkan peserta didik untuk dapat menjalankan peranan yang menuntut perluasan pengetahuan 
khusus tentang ajaran agama bersangkutan, (Menteri Pendidikan dan Kebudayaan, 1993:21).

Dengan keterangan di atas maka jelaslah bahwa pendidikan agama harus dimasukkan kedalam kurikulum mulai dari sekolah Taman Kanak-Kanak sampai ketingkat perguruan tinggi baik itu negeri maupun swasta.

\section{c) Dasar Operasional}

Dasar operasional maksudnya adalah dasar yang diambil dari ketetapan MPR RI yang secara langsung mengatur pelaksanaan pendidikan agama ddi sekolah-sekolah seluruh indonesia. MPR adalah lembaga tertinggi di mana hal-hal yang telah menjadi keputusan MPR harus dilakssnakan, termasuk dalam hal ini pendidikan agama yang tela disebut dalam ketetapan MPR RI No.II/MPR/1983, berbunyi sebagai berikut: Dengan semakin meningkat dan meluasnya pembangunan, maka kehidupan keagamaan dan kepercayaan kepada Tuhan Yang Maha Esa harus semakin terus diamalkan baik didalam kehidupan pribadi maupun sosial kemasyarakatan.

Diusahakan supaya terus bertambah sarana-sarana yang diperlukan bagi kehidupan keagamaan dan kepercayaan terhadap Tuhan Yang Maha Esa, termasuk pendidikan agama yang dimasukkan kedalam kurikulum di dalam sekolah-sekolah mulai dari sekolah dasar sampai dengan universitas-universitas negeri ataupun swasta. (UUD 45, P4, GBHN 1983:126)

Memperhatikan uraian-uraian di atas maka jelaslah bahwa pendidikan agama di indonesia memiliki dasar yang kuat dan kukuh dan tidak diragukan lagi sebagai pegangan para pendidik dalam menjalankan tugasnya sebaai guru.

\section{d) Agama Islam Dasar Sosial Psikologis}

Secara psikologis setiap orang yang hidup di dunia in cendrung untuk memerlukan perlindungan hal itu terbukti apabila seseorang mengalami kesulitan niscaya ia akan sadar dan ia akan segera mencari kekuasaan di luar dirinya. Dan hal tersebut membuktikan bahwa seseorang sangat membutuhkan pegangan hidup guna memberikan rasa aman pada dirinya. Terkait dengan semua itu, menurut islam satu-satunya jalan untuk memperoleh rasa aman dalam hidup ini adalah dengan jalan mendekatkan diri dan mengabdikan diri kepada zat yang maha kuasa.

\section{Tujuan Pendidikan Agama}

Tujuan adalah apa yang ingin dicapai oleh suatu usaha atau pekerjaan atau dengan kata lain tujuan adalah hasil yangg akan dicapai setelah melakukan usaha atau pekerjaan yang memang mesti mempunyai tujuan, sebab suatu usaha yang tidak mempunyai tujuan tertentu pada dasarnya adalah suatu usaha yang tidak terarah. Sehubungan dengan hal ini Ahmad D. Marimba mengatakan bahwa suatu usaha yang tidak mempunyai tujuan tidaklah mempunyai apa-apa, oleh karena itu sukarlah kiranya kita mendapatkan contoh-contoh yang tidak bertujuan, (Pengantar Filsafat Pendidikan Islam, 1994:48). Sedangkan menurut Zuhairani, tujuan pendidikan adalah membimbing anak agar mereka menjadi muslim sejati, beriman teguh dan beramal sholeh, berakhlak mulia dan berguna bagi masyarakat, (1993:45).

Prof. Dr. H.M.Arifin merumuskan tujuan tujuan pendidikan agama islam adalah mewujudkan kepribadian muslim yang sempurna dalam mengembangkan

$$
\text { 56| Edisi } 2 \text { No.2 Juli } 2020
$$


kehidupan dunia akhiratnya di atas landasan iman dan taqwa kepada Allah SWT, (1996:133).

Drs. Abdul Rahman Shaleh mengatakan tujuan pendidikan agama islam adalah usaha memberikan bantuan kepada manusia yang dewasa supaya cakap dalam menyelesaikan tugas hidupnya yang diridoi Allah swt, sehingga terjamin kebahagiaan dunia akhirat, (Didaktik Pendidikan Agama, 1996:36).

Al-Ghazali menjelaskan, tujuan dari Pendidikan Agama adalah mendekatkan diri kepada Allah SWT. Bukan pangkat atau jabatan yang tinggi dan bermegah-megahan, maka jnganlah seseorang pelajar itu belajar untuk mencari pangkat, jabatan dan harta, atau untuk menipu orang-orang bodoh dan bermegah-megahan dengan kawan, (Dr. Moh.Athiyah Al-Abrasy, 1970:15).

Djumhur dan H. Dana Saputra mengungkapkan bahwa tujuan pendidikan agama islam adalah:

b) Menanamkan kepercayaan tentang adanya Tuhan yang wajib disembah dan pada semua utusan-utusan-Nya, diantaranya kepada Nabi Muhammad SAW sebagai utusan Allah yang terakhir.

c) Menanamkan akhlak untuk manusia yang menjadi pribadi dan anggota masyarakat yang berbudi luhur dan sanggup menegakkan kebenaran sesuai dengan ajaran Islam, (1975:21).

Dengan memperhatikan tujuan pendidikan islam seperti termaktub di atas maka dapatlah diambil kesimpulan bahwa pendidikan agama Islam mempunyai tujuan untuk membimbing dan menunntun anak dengan akhlak mulia sehingga anak bertaqwa kepada Allah SWT dengan menjalankan segala perintah-Nya dan menjauhi segala larangan-Nya.

\section{Peranan Pendidikan Agama Bagi Santri}

Sebagaimana telah dijelaskan pada uraian-uraian di atas bahwa pendidikan agama adalah memberikan bimbingan dan tuntunan kepada anak didik agar menjadi dewasa jasmani dan rohani serta dapat menjlankan ajaran agama menurut islam. Ungkapan atau pengertian ini memberikan satu doktrin bahwa pendidikan agama ini harus ditanamkan kepada anak sedini mungkin. Jika demikian maka dapatlah dimengerti bahwa pendidikan agama adalah merupakan suatu tugas yang sangat mulia dan luhur karena bertujuan untuk membina dan membentuk manusia menjadi muslim sejati yang senantiasa bertaqwa kepada Allah SWT.

\section{Pendidikan Agama dalam Rumah Tangga}

Ketahuilah bahwa sesungguhnya Ibu rumah tangga adalah pendidik yang asli bagi anaknya semenjak bayi baru lahir sampai dengan anak dewasa ia tetap dalam bimbingan ibu. Ia tetap menerima kasih sayang dari ibunya, semenjak masih bayi sampai kanak-kanak berusia 5 atau 6 tahun anak tersebut akan senantiasa mengikuti bundanya oleh karena itu kita harus mampu mengkaji secara mendalam sejauh mana pendidikan keluarga ini dikatakan berhasil.

Dalam hal ini tentu kita mengakui secara sadar bahwa setiap orang tua akan senantiasa bercita-cita untuk mendidik anak-anaknya agar menjadi anak yang berakhlak mulia dan bersopan santun terpuji. Hal inilah yang paling banyak mendorong orang tua untuk senantiasa berusaha semaksimal mungkin dalam memberikan pendidikan bagi anak-anaknya. Cara orang tua mendidik anaknya

$$
\text { 57| Edisi } 2 \text { No.2 Juli } 2020
$$


besar pengaruhnya pada belajar anaknya, bahwa keluarga adalah tempat pendidikan yang pertama dan utama. Pendidikan keluarga yang bersifat informal utama dan pertama yang dialami oleh anak da lembaga pendidikan yang bersifat kodrati. Pendidikan anak-anak disekolah merupakan kelanjutan pendidikan anakanak yang dilakukan orang tua dirumah. Berhasil tidaknya pendidikan di sekolah tergantung pada keluarga dan dipengarihu oleh pendidikan didalam keluarga. Pendidikan keluarga adalah fundamen atau dasar dari pendidikan anak selanjutnya baik di sekolah maupun di masyarakat.

Pentingnya pendidikan dalam keluarga bagi perkembangan anak menjadi manusia yang berkepribadian dan berguna bagi masyarakat. Hal ini telah dinyatakan oleh para ahli tentang pendidikan dalam keluarga. Al Ghazali mengatakan: Dan anak adalah suatu rahmat Tuhan kepada orang tuanya, hati yang suci bagaikan juhar yang indah sederana dan bersih dari segala goresan dan bentuk. Ia masih menerima segala apa yang digoreskan kepadanya dan cendrung kepada setiap hal yang ditujukan kepadanya. (Zakiah Darajat, 1992:99).

Dari perkataan di atas, dapat dinyatakan bahwa tanggung jawab keluarga yakni kedua orang tua terhadap pendidikan anak meliputi dua macam alasan yaitu:

a) Anak lahir dalam keadaan suci, bersih dan sederhana. Hal ini menunjukkan bahwa anak lahir dalam keadaan tidak berdaya dan belum berbuat apa-apa, sehingga masih sanagt menggantungkan diri pada orang lain yang lebih dewasa. Orang tua (ayah bunda) adalah tempat mengantungkan diri dan tempat berlindung secara wajar berdasarkan atas adanya hubungan antara anak dan kedua orang tua.

b) Kelahiran anak didunia ini, adalah merupakan akibat langsung dari perbuatan orang tuanya. Oleh karena itu kedua orang tua sebagai orang yang telah dewasa harus menanggung segala resiko yang timbul sebagai akibat perbuatan (aktivitas) usahanya, yaitu bertanggung jawab atas pemeliharaan dan pendidikan anak-anak sebagai amanat Tuhan yang wajib dilaksanakan, (Zakiah Darajat, 1992:57).

Dengan demikian orang tua adalah orang yang pertama dan utama yang wajib bertanggung jawab atas pemeliharaan dan pendidikan anak-anaknya. Tanggung jawab pertama karena dalam keluargalah anak-anak pertama kali menyandarkan hidup dan membutuhkan kasih saying pertama, mendapatkan bimbingan, pengajaran dan pendidikan dari orang tuanya. Sebagai tanggung jawab terutama, karena sebagian besar kehidupan anak adalah didalam keluarga, sehingga pendidikan dan bimbingan yang paling banyak diterima oleh anak adalah dari orang tua. Pendidikan anak sejak lahirnya harus mendapatkan perhatian sepenuhnya dari orang tuanya karena pendidikan mempunyai peranan yang penting dan besar sekali pengaruhnya terhadap pertumbuhan dan perkembangan anak. Bila sejak kecil anak dibiarkan begitu saja, maka berpengaruh negatif pada perkembangannya.

Dalam pemberian pendidikan terhadap anak-anak baik pendidikan agama maupun pendidikan umum harus disesuaikan dengan perkembangan anak sejak kecil Demikian pula dalam proses belajar anak diperlukan bantuan dan bimbingan

$$
\text { 58|Edisiz No.2 Juli } 2020
$$


dari orang tuanya atau anggota keluarga sehingga anak merasa terangsang atau terpanggil jiwanya untuk belajar sekaligus mempertinggi mutu belajarnya sehingga dapat mencapai prestasi seperti yang diharapkan. Dengan adanya kasih sayang yang ditunjukkan orang tua akan dapat memberikan ketenangan ketika belajar. Setiap orang tua pasti mendambakan anaknya sukses dalam pendidikan, oleh sebab itu orang tua hendaknya berusaha memberikan bantuan baik berupa bimbingan, pengawasan dan memberikan motivasi agar harapannya dapat tercapai. Adapun bentuk-bentuk kerjasama yang dilakukan orang tua dalam mendidik anak antara lain:

a) Menyediakan fasilitas belajar. Setiap anak membutuhkan fasilitas dalam belajarnya seperti alat tulis, buku pelajaran dan tempat belajar.

b) Mengawasi kegiatan belajar anak dirumah. Sebagai orang tua hendaknya selalu tetap bias mengawasi anak tetap dirumah dalam kegiatan belajarnya, karena orang tua turut bertanggung jawab atas kemajuan study anaknya.

c) Mengawasi penggunaan waktu belajar. Hendaknya orang tua mengawasi waktu belajar yang telah dijadwalkan

d) Menolong anak dalam mengatasi kesulitan belajar. Jika orang tua berusaha ikut membantu kesulitan anaknya dalam kegiatan belajar berarti orang tua berusaha menolong agar berhasil dalam belajar.

Dari urain di atas dapat diketahui bahwa baik buruknya watak serta perilaku anak terletak bagaimana peranan orang tua atau keluarga dalam mendidik anak, karena pendidikan keluarga merupakan sebagai peletak dasar pembentukan kepribadian anak. Dalam hal ini peran orang tua sangat menentukan. Mereka berdua memikul tanggung jawab seluruh keluarga, mereka yang akan menentukan kemana akan dibawa, retaknya suatu rumah tangga mengakibatkan anak yang tumbuh dan berkembang dalam lingkungan rumah tangga semacam ini merasa kurang perhatian dan kasih sayang dari orang tuanya. Oleh karena itu dalam menyiapkan dan membentuk pribadi anak menjadi apa yang diinginkan orang tua khususnya dan para pendidik pada umumnya, maka kedua lembaga ini harus bekerja sama untuk saling mengerti dan mengetahui tentang anak yang pendidikannya menjadi tanggung jawabnya, hingga anak memperoleh keuntungan dari pola perkembangan pendidikannya.

Untuk itu dalam menghadapi anak-anak sukar didalam kelas membuktikan tentang keharusan adanya kerlasama antar keluarga dan sekolah. Oleh karena itu sesuai dengan pokok pembahasan jurnal ini yaitu bagaiman fungsi bimbingan keluarga terhadap prestasi belajar anak. Untuk itu keluarga dapat membantu sekolah/guru dengan:

a) Keluarga membiasakan anak taat, terus terang, dapat dipercaya jujur dalam perbuatan dan ucapan.

b) Keluarga menunjukkan simpatinya terhadap segala pekerjaan yang dikerjakan oleh guru serta membantu sekuat tenaga dalam mendidik anak-anaknya.

c) Keluarga memperhatikan kontinyuitas anak-anak setiap hari sekolah, dan memperhatikan juga keberesan kewajiban rumah, da mendorong anaknya untuk menepati segala yang diperintahkan oleh sekolah, (Arifin, 1996:111).

d) Keluarga membiasakan anak taat di dalam menjalankan segala perintah orang tua, perintah guru dan yang paling utama adalah perintah Allah. Itulah yang

$$
\text { 59| Edisi } 2 \text { No.2 Juli } 2020
$$


paling utama dikerjakan oleh setiap insan. Keluarga membiasakan anak terus terang didalam segala yang diperitahkan oleh guru, baik itu merupakan kewajiban disekolah maupun diluar sekolah, misanya di dalam pembayaran SPP atau Iuran Komite Sekolah, membeli alat sekolah lainnya, disini antara orang tua dengan anak harus ada sifat keterbukaan sehingga orang tua merasa tidak ragu didalam menyekolahkan anaknya, begitu juga sebagai anak tidak dihantui oleh perasaan-perasaan yang tidak-tidak sehingga di dalam menerima pelajaran selalu tenang.

e) Selama anak sekolah, orang tua/keluarga membantu guru dalam pelaksanaan tugasnya, sedang bantuan tersebut merupakan realisasi dari ikatan saling pengertian dan kerjasama yang sangat diperlukan bagi kemajuan anak baik di sekolah maupun di luar sekolah.

f) Dalam hubungan dengan sekolah, orang tua/keluarga mempunyai kewajiban yang perlu diakui oleh sekolah, seorang pendidik mengerti dan merasa perlu untuk meberikan hak itu kepada orang tua/keluarga demi suksesnya tujuan pendidikan yang menjadi tanggung jawab keluarga dan sekolah. Oleh karena itu orang tua/keluarga perlu melibatkan diri dalam usaha sekolah memberikan pelayanan kepada anak, orang mengerti dengan persoalan-persoalan yang dialami oleh anaknya dan orang tua mengerti akan fasilitas-fasilitas yang diberikan, oleh sekolah kepada anak dalam memenuhi kebutuhan sekolahnya. Untuk itu orang tua/keluarga minta beli itu, beli ini tidak perlu menyalahkan sekolah atau guru, karena memang begitu keadaan sekolah, dan ini merupakan dorongan atau bimbingan yang bersifat kongrit yang diberikan orang tua kepada anaknya didalam meningkatkan prestasi belajarnya. Bila anak-anak sedang asyik belajar, ada kalanya orang tua suka mengganggu dengan pekerjaan rumah sehingga belajarnya terhenti, sebetulnya anak sangat membutuhkan bimbingan dan dorongan moril dari orang tua dalam hal belajar. Anak yang selalu dibebani oleh pekerjaan rumah, sehingga anak tidak berkesempatan untuk membuka buku pelajarannya dan penunaian tugas sekolah menjadi lemah. Oleh karena itu pengertian orang tua/keluarga sanagt dibutuhkan demi peningkatan prestasi belajar anak.

Dari uraian di atas dapat di simpulkan bahwa bila keluarga tidak menaruh perhatian dan membantu atau tujuan pendidikan rumah bertentangan dengan di sekolah, maka akan terjadi pengaruh yang saling bertentangan. Keadaan yang demikian akan menimbulkan pelanggaran dan pembangkangan anak, secara otomatis pendidikan anak akan terbengkalai dan prestasinya akan menurun. Oleh karena itu fungsi orang tua/keluarga adalah mengembangkan bakat-bakat pada anak melalui jalur-jalur pendidikan.

\section{B. Metode Penelitian}

Setiap penelitian harus mempunyai perencanaan, untuk itu diperlukan suatu disain penelitian yang merupakan rencana tentang cara mengumpulkan data, menganalisis data agar dapat dilaksanakan secara ekonomis serta serasi dengan tujuan penelitian, (Nasution, 1996:23).

Dalam penelitian ini penulis menggunakan pendekatan atau metode penelitian yang bersifat kualitatif yaitu suatu penelitian yang berorientasi pada

$$
\text { 60| Edisiz No.2 Juli } 2020
$$


gejala atau penomena yang bersifat alami. Mengingat orientasinya demikian maka sifatnya fundamental dan naturalistik atau bersifat alamiah serta tidak bisa dilakukan dilaboratorium melainkan dilapangan, (Ali, 1992:159). Menurut pendapat yang lain, metode kualitatif adalah prosedur penelitian yang menghasilkan data diskriftif, ucapan atau tulisan dan perilaku yang diamati dari orang-orang atau subyek itu, (Farchan, 1992:21). Dengan demikian dalam menggunakan metode penelitian yang bersifat kualitatif, penelitian hanya menggunakan apa adanya dari ucapan, tulisan dan perilaku dari obyek yang diteliti. Penelitian yang dilakukan dengan menggunakan pendekatan kualitatif, mempunyai ciri-ciri tertentu. Adapun ciri-cirinya adalah sebagai berikut:

1) Tatanan alami merupakan sumber data yang bersifat lansung dan peneliti itu sendiri menjadi instrumen kunci.

2) Bersifat deskriptif

3) Penelitian kualitatif memperdulikan proses, bukan hasil atau produk

4) Analisa datanya bersifat induktif

5) Kepedulian utama penelitian kualitatif adalah pada makna, (Ali, 1992:160).

Setelah bahan-bahan atau data-data terkumpul, maka selanjutnya adalah menganalisa data-data tersebut, adapun dalam menganalisis data, penulis menggunakan metode analisis sebagai berikut:

\section{Metode Induksi}

Metode induksi adalah berfikir dari soal-soal yang khusus membawanya kepada kesimpulan-kesimpulan yang umum atau dapat dikatakan juga dengan berfikir dari soal-soal yang konkrit pada soal-soal yang abstrak, (Bakri, 1990: hal.132).

Drs. H. Hasbullah Bakri mendefinisikan metode ini sebagai berikut: Kalau kita mempunyai beberapa kesimpulan umum lalu kita menarik kesimpulan khusus tentang sesuatu itulah yang dinamakan suatu pemikiran deduksi. Jadi metode induksi adalah suatu teknik yang cara bekerjanya dimulai dari suatu observasi atas sesuatu yang konkrit (khusus umpamanya atas penyelenggaraan sekolah), kemudian hasil observasi diolah atau dipikirkan yang kemudian di simpulkan serta dinyatakan sebagai suatu hal yang berlaku umum.

Berdasarkan keterangan di atas dapatlah penulis menarik suatu kesimpulan bahwa metode induksi adalah suatu sistem pemikiran untuk mendapatkan kesimpulan dimana penganalisaan data dimulai dari hal-hal yang sifatnya khusus untuk sampai pada hal-hal yang sifatnya umum. Metode ini penulis mempergunakan untuk mengolah dan menganalisa data tentang peranan pendidikan agama Islam bagi anak.

\section{Metode Deduksi}

Metode deduksi adalah sesungguhnya merupakan kebalikan dari metode induksi. Sedangkan metode deduksi merupakan suatu sistem atau cara berpikir dari hal-hal yang sifatnya khusus, maka metode deduksi akan menetapkan aturannya dari hal-hal yang sifatnya umum menjadi khusus. Drs. H. Hasbullah Bakri mendefinisikan metode ini sebagai berikut: Kalau kita mempunyai beberapa kesimpulan umum lalu kita menarik kesimpulan khusus dari sesuatu itulah yang dinamakan metode deduksi. Dengan kata lain dapat penulis kemukakan metode

$$
\text { 61|Edisiz No.2 Juli } 2020
$$


deduksi adalah suatu metode pengolahan data dengan jalan menarik kesimpulan dari ha-hal yang bersifat umum untuk sampai pada yang khusus.

Dalam metode ini penulis menganalisis data tentang peranan Madrasah Ibtidaiyah NW Al-Akhyar Bagik Polak Barat Kecamatan Labuapi Kabupaten Lombok Barat sebagai wadah pendidikan agama bagi anak didik. Demikianlah metode yang penulis paparkan dalan mengolah data, menganalisis data dan dalam usaha penyusunan jurnal ini.

Adapun tehnik analisis data yang digunakan dalam penelitian ini adalah tehnik analisis yang berbentuk kuantitatif atau disebut juga dengan analisis statistik. Untuk dapat menarik kesimpulan dari data yang diperoleh, maka teknik analisis yang diterapkan adalah metode statistika dengan rumus t- tes untuk sebuah kasus sebagai berikut:

$$
t=X \pm t_{0,05} \sqrt[S /]{n} \quad \text { (Soepeno, 1997):138) }
$$

Keterangan:

$\bar{X} \quad=$ Rata-rata sikap siswa terhadap Keteladanan guru .

$\mathrm{T}$

$0,05=$ Taraf signifikasi dalam tabel berdarakan $\mathrm{db}=\mathrm{n}-1$

$\mathrm{S}=$ Standar deviasi sampel

$\mathrm{N} \quad=$ Jumlah subjek penelitian

Penggunaan rumus di atas didasarkan pada suatu argumentasi yang menyebutkan bahwa penggunaan t-tes untuk satu kasus sampel skala data yang diperkenankan adalah data berskala interval dan biasanya digunakan untuk uji batas keyakinan, (Soepeno, 1997:134).

Dari penjelasan tersebut, maka berarti bahwa Tujuan Pendidikan Dalam Islam Dalam Kehidupan Santri di Madrasah Ibtidaiyah NW Al-Akhyar Bagik Polak Barat Kecamatan Labuapi Kabupaten Lombok Barat pada mata pelajaran Pendidikan Agama Islam dapat berbentuk positif atau negatif.

\section{Temuan Penelitian dan Pembahasan}

1. Dasar dan Tujuan Pendidikan Agama Islam di MI NW Al-Akhyar Bagik Polak Barat Kecamatan Labuapi Kabupaten Lombok Barat

Dasar dan tujuan pendidikan agama Islam di Madrasah Ibtidaiyah NW AlAkhyar Bagik Polak Barat Kecamatan Labuapi Kabupaten Lombok Barat mempunyai dasar yang cukup kuat, dasar-dasar tersebut antara lain:

d) Yuridis / hukum

Yang dimaksud dengan dasar yuridis atau hukum ini adalah dasar-dasar pelaksanaan pendidikan yang berasal dari peraturan-peraturan atau undangundang secara langsung maupun tidak langsung dapat dijadikan pegangan dalam pelaksanaan pendidikan agama Islam di sekolah negeri maupun swasta.

e) Religius

Yang dimaksud dengan dasar religius adalah dasar-dasar yang bersumber dari wahyu illahi dan hadis nabi SAW karena kedua dasar tersebut adalah sumber pokok dari agama Islam.

f) Sosial psikologis

$$
\text { 62|Edisiz No.2 Juli } 2020
$$


Secara psikologis setiap orang yang hidup di dunia ini cenderung untuk memerlukan perlindungan, membutuhkan pegangan hidup guna memberikan rasa aman pada dirinya.

Adapun tujuan pendidikan agama Islam Madrasah Ibtidaiyah NW Al-Akhyar Bagik Polak Barat Kecamatan Labuapi Kabupaten Lombok Barat penulis dapat paparkan dari hasil wawancara dengan Wakamad antara lain: (1) Untuk meningkatkan keimanan dan ketakwaan pada Allah SWT. (2) Untuk meningkatkan penghayatan dan pengamalan agama dalam rangka mempertinggi akhlak, memperkuat mental dan moral bagi anak didik MI NW Al-Akhyar Bagik Polak Barat Kecamatan Labuapi Kabupaten Lombok Barat. Menghindari kecenderungan pendangkalan, pengertian, pemahaman kehidupan spiritual keagamaan. Membina persatuan dan kesatuan bangsa dalam pembangunan nasional. (3) Meningkatkan peranan agama sebagai motivasi dan juga semangat pembangunan serta sebagai penggerak dan pengaruh potensi umat beragama. (4) Menanggulangi dampak negatif dari modernisasi yang berbentuk praktek kultural yang tidak sesuai dengan kepribadian bangsa dan norma-norma agama. (5) Mengimbangi dan mengadakan adaptasi dalam proses modernisasi dalam bentuk pembangunan pikiran-pikiran ilmiah dalam cara menghayati dan mengamalkan Agama, (Johaini, S.Pd., wawancara tanggal 23 Maret 2020).

Demikian uraian dasar dan tujuan pendidikan agama Islam di Madrasah Ibtidaiyah NW Al-Akhyar Bagik Polak Barat Kecamatan Labuapi Kabupaten Lombok Barat. Dengan demikian anak didik di MI NW Al-Akhyar Bagik Polak Barat Kecamatan Labuapi Kabupaten Lombok Barat ini akan mampu menghadapi segala problematika hidup dan kehidupan yang akan dialami dalam kondisi moral yang diridhoi oleh Allah SWT.

\section{Peranan MI NW Al-Akhyar Bagik Polak Barat Kecamatan Labuapi Kabupaten Lombok Barat Dalam Pendidikan Agama Islam Bagi Anak Didik}

Seperti kita maklumi bahwa MI NW Al-Akhyar Bagik Polak Barat Kecamatan Labuapi Kabupaten Lombok Barat adalah lembaga pendidikan agama Islam, maka cepat atau lambat tentu memegang peranan dan arti tersendiri bagi anak didiknya di dalam kehidupan keluarga maupun masyarakat. Semenjak berdirinya madrasah ini pada tanggal 28 Desember 1978, sedikit demi sedikit telah menanamkan suatu keyakinan bagi masyarakat bahwa MI NW Al-Akhyar Bagik Polak Barat Kecamatan Labuapi Kabupaten Lombok Barat ini sangat berperan dalam meningkatkan perananya dalam mengembangkan pendidikan agama Islam serta ikut mencapai kemajuan ilmu pengetahuan, sehingga tidaklah mengherankan kalau animo, semangat belajar anak didik melaju terus untuk menunjukkan kemajuan yang pesat dan menimbulkan suatu rangsangan untuk lebih meningkatkan kualitas belajar anak didik.

Peranan MI NW Al-Akhyar Bagik Polak Barat Kecamatan Labuapi Lombok Barat ini terhadap perilaku anak didiknya tampak sekali terutama cara merubah cara berpikir dan bersikap. Cara berpikir sempit dan statis kini dirubah menjadi kreatif dan dinamis, cara bersikap terhadap anti kemajuan kini dirubah menjadi pelopor kemajuan. Dengan berubahnya sikap dan cara berpikir mereka (anak didik) maka kita dapat melihat kenyataan-kenyataan yang merupakan respek

$$
\text { 63|Edisiz No.2 Juli } 2020
$$


positif berdirinya MI NW Al-Akhyar Bagik Polak Barat Kecamatan Labuapi Kabupaten Lombok Barat, (Johaini, S.Pd., Wawancara 16 Maret 2020).

Dengan demikian pembahasan di atas ini dapatlah kita mengetahui kenyataan-kenyataan yang merupakan peranan langsung atas berdirinya MI NW Al-Akhyar Bagik Polak Barat Kecamatan Labuapi Kabupaten Lombok Barat terhadap anak didik. Hal ini dapat dibuktikan dengan pelajar-pelajarnya yang berdatangan dari luar desa sehingga demikian para pendidik dan pendirinya senantiasa meningkatkan fasilitas pelayanannya terhadap pelajar-pelajarnya.

Jadi untuk mengetahui sejauh mana peranan Madrasah Ibtidaiyah NW AlAkhyar Bagik Polak Barat Kecamatan Labuapi Kabupaten Lombok Barat terhadap pendidikan anak didik akan diperlukan data-data konkrit, valid serta obyektif. Oleh karena itu penulis melakukan wawancara dengan Kepala Sekolah, guru agama, masyarakat dan sumber lainnya.

Menurut kepala sekolah peranan pendidikan agama Islam sangat besar artinya bagi anak didik untuk menyongsong era globalisasi dewasa ini yang semakin canggih yang harus dibekali dengan imtak. Tujuan yang ingin dicapai dengan pendidikan agama Islam ini adalah sejalan dengan tujuan Islam yaitu amal makruf nahi munkar. Atas dasar ini kita dapat berkata bahwa tujuan pendidikan agama Islam adalah membina anak didik secara pribadi dan kelompok sehingga mampu menjalankan fungsinya sebagai hamba Allah dan khalifah-Nya guna membangun dunia ini sesuai dengan konsep yang ditetapkan Allah yaitu alQur'an, (Wawancara dengan kepala sekolah, 16 Maret 2020). Senada dengan guru Pendidikan Agama (Juniadin Hudri, S.Pd., M.Pd.) menyoroti tentang adanya perubahan perilaku anak didik dari sudut pandang teologi keagamaan masyarakat. Misalnya dari segi sholat lima waktu anak didik sudah mulai melakukannya secara pribadi atau berjamaah. Karena di sekolah dijadwalkan juga kegiatan mingguan dan bulanan seperti: (1) Mengadakan pengajian-pengajian, (2) Melaksanakan pesantren kilat, (3) Memperingati hari-hari besar agama Islam seperti Maulid nabi Saw dan isra' mikraj.

Demikianlah sekilas peranan MI NW Al-Akhyar Bagik Polak Barat Kecamatan Labuapi Kabupaten Lombok Barat terhadap pendidikan agama Islam bagi anak didiknya begitu penting dalam meningkatkan sumber daya manusia yang dibekali dengan imtak (iman dan takwa). Adapun kenyataan-kenyataan tersebut antara lain:

a) Masyarakat/orang tua memiliki kesadaran yang lebih tinggi untuk menyekolahkan anak-anaknya ke jenjang yang lebih tinggi

b) Timbulnya suatu sikap bagi anak didik untuk merubah perilaku menjadi lebih baik

c) Adanya tuntunan untuk lebih meningkatkan pendidikan anak didik baik dari segi kualitas maupun tingkatnya, misalnya mendirikan MTs. dan lainnya.

\section{Proses Pembinaan Pendidikan Agama Islam dalam Merubah Perilaku Anak Didik di Madrasah Ibtidaiyah NW Al-Akhyar Bagik Polak Barat Kecamatan Labuapi Kabupaten Lombok Barat}

Berdasarkan hasil wawancara dengan Kepala Madrasah/Wakil Kepala MI NW Al-Akhyar Bagik Polak Barat Kecamatan Labuapi Lombok Barat jenis kegiatan belajar mengajar dalam rangka proses penanaman pendidikan agama Islam dapat

$$
\text { 64|Edisiz No.2 Juli } 2020
$$


dibagi menjadi beberapa bagian. Pertama, pada waktu aktif belajar antara pukul 07.30-13.00. Kedua, bentuk kegiatan ekstrakulikuler. Dan ketiga, kegiatan kokurikuler (wawancara kepala sekolah, 16 Maret 2020).

Jenis kegiatan pertama merupakan kegiatan yang dilakukan selama proses belajar mengajar yang berlangsung di kelas. Peneliti melakukan observasi terhadap kegiatan proses belajar mengajar yang dilaksanakan di dalam kelas. Dimana ini merupakan kegiatan yang esensial dalam menanamkan, meningkatkan iman dan takwa. Sedangkan lazimnya seorang guru segala kegiatan dalam kelas telah dipersiapkan dari program tahunan, program semester, satuan pembelajaran dan rencana pembelajaran yang dilakukan oleh guru-guru. Peningkatan keagamaan tidak hanya dilakukan di dalam kelas melainkan pada sore hari, juga diadakan kegiatan ekstrakulikuler seperti les dan pelajaran Diniyah Islamiyah. Demikian penegasan guru-guru di MI NW Al-Akhyar Bagik Polak Barat Kecamatan Labuapi Kabupaten Lombok Barat.

Adapun kegiatan yang berjangka dalam waktu tertentu seperti pengajian rutin hari Jumat, pengajian rutin hari besar Islam dan kegiatan-kegiatan yang dapat menungkatkan pengetahuan agama dan akhlakul karimah, (wawancara Wakamad, 17 Maret 2020).

Menurut penjelasan sebagian guru di Madrasah Ibtidaiyah NW Al-Akhyar Bagik Polak Barat Kecamatan Labuapi Kabupaten Lombok Barat problem yang paling esensial dihadapinya dalam kegiatan belajar mengajar adalah mengenai alokasi waktu. Seringkali materi pelajaran tidak dapat diselesaikan tepat waktu.

Selain dari pada itu para siswa-siswi membuat program di luar jam pelajaran di madrasah seperi kelompok diskusi dan les. Hal ini sangat mendukung dalam rangka meningkatkan pengetahuan serta penanaman pendidikan agama Islam menuju terbentuknya kepribadian muslim yang sejati (observasi 16 Maret 2020).

Demikian sekilas penulis paparkan mengenmai proses penanaman Pendidikan Agama Islam di Madrasah Ibtida'iyah NW Al-Akhyar Bagik Polak Barat Kecamatan Labuapi Kabupaten Lombok Barat

Sehubungan dengan pembahasan di atas, maka penulis dapat mengambil kesimpulan sebagai berikut:

1. Pendidikan agama Islam merupakan salah satu bidang studi yang sangat penting dipelajari oleh setiap umat Islam untuk mencapai kebahagian baik di dunia maupun diakhirat serta merupakan alat untuk mengantarkan umat kepada terbentuknya kepribadian manusia yang muslim sejati

2. Menuntut ilmu adalah merupakan sebuah kewajiban yang harus dilaksanakan oleh setiap umat Islam dan menuntut ilmu tidak ada batas waktunya. Islam mengajarkan pendidikan seumur hidup yaitu pendidikan dari buaian sampai liang kubur.

3. Pendidikan agama memegang peranan penting dalam hidup dan kehidupan kita, dan merupakan suatu usaha yang harus dijalankan kepada anak didik karena cita-cita keagamaan itu mempunyai nilai yang lebih tinggi dan lebih luas dari yang lainnya. Agama itu menyangkut masalah keyakinan atau iman yang membutuhkan kecermatan dan ketekunan serta kita harus mengerti

$$
\text { 65|Edisi } 2 \text { No.2 Juli } 2020
$$


benar-benar bagaimana menyajikannya terhadap anak didik agar tujuan yang diinginkan dapat dicapai dengan baik.

4. Tugas dan tanggung jawab orang tua sebagai pendidik sangat besar pengaruhnya terhadap anak didik. Sebab orang tua dalam keluarga/rumah tangga adalah orang yang pertama dikenal oleh anak.

5. Anak adalah makhluk yang sedang berkembang menuju ke arah kesempurnaan (dewasa). Setingkat demi setingkat perkembangan anak adalah perkembangan fungsi-fungsi jiwa anak secara keseluruhan. Masingmasing berhubungan dengan yang lainnya pada masing-masing tingkat perkembangan itu memerlukan bimbingan dan pimpinan. Maka disinilah peran dan fungsi orang tua dalam memberikan bimbingan dan pendidikan kepada anak.

6. Tujuan pendidikan agama adalah menyiapkan anak-anak supaya kelak cukup melakukan pekerjaan yang membahagaiakan dirinya sesuai dengan norma dan aturan-aturan agama Islam. Menciptakan anak agar dapat berbakti pada orang tuanya, mengetahui dan mengamalkan ajara-ajaran agamanya, baik yang berhubungan dengan pribadinya, masyarakatnya maupun yang langsung berhubungan dengan tuhannya.

7. Keadaan guru dan perkembangan muridnya cukup maju dan berkembang sesuai dengan era pembangunan khususnya di bidang pendidikan dan kebudayaan. 


\section{Daftar Rujukan}

Abdullah, Pius, 1994, Kamus Besar Indonesia, Surabaya : Arkola

Al-Qur'an dan Terjemahannya, 1999. Departemen Pendidikan Agama, Mahkota Drajat Zaskiyah, dkk. 1996. Metodologi Pengajaran Agama Islam, Jakarta, Aksara Heri Noer Ali, 1999. IImu Pendidikan Islam, Jakarta, Logos Wacana Ilmu

Muhazir, Noeng 1992, Metodologi Penelitian Kualitatif, Yogyakarta : Rake Serasin Muhaimin dkk, 1993. Pemikiran Pendidikan Islam, Bandung: Trio Ganda Karya Marimba Ahmad D, 1992. Pengantar Filsafat Pendidikan Islam, Bandung al-Makrif Nasution, 1994. Metodologi Research, Jakarta, Bina Aksara

Nawawi, hadari, 1994. Manusia Berkualitas, Yogyakarta, Gajag Mada University Nawawi Muhamah Umar, 1995. Terjemahan Tamihul Qoul, Mutiara Ilmu Surabaya Nizar, Samsul, 2001. Dasar-Dasar Pemikiran Pendidikan Islam, Jakarta: Gaya Media Pratama

Pidarta, Made 1999. Pemikiran Tentang Supervisi Pendidikan, Jakarta, Bumi Aksara

Rama Yulis, 1994, Ilmu Pendidikan Islam, Jakarta: Kalam Muya

Sardiman, 1992. Motivasi Belajar Mengajar, Jakarta: Rajawali Press

Shaleh, Abdullah Rachman, 1993. Didaktik Pendidikan Agama, Jakarta Bulan Bintang

Slameto, 1992, Motivasi Belajar Mengajar, Jakarta: Rajawali Press

Suharsini, AriKunto, 1998 Prosedur Penelitian Suatu Pendekatan Praktek, Jakarta: Rineksa Cipta,

Syam Noor, 1997 Pengantar Dasar-Dasar Pendidikan, Surabaya, Usaha Nasional

Tafsir, Ahmad, 1995, Metodologi Pengajaran Agama Islam, Bandung Remaja Karya

Ulwan, Abdullah Nasih, 1991, Pedoman Pendidikan Agama Dalam Is/am, Jakarta: Assyafi'i

Usman, Muh, User, 1995, Menjadi Guru Yang Profesional, Bandung Remaja Rosda Karya

Undang-Undang No.2 1995, Sistem Pendidikan, Semarang Aneka Ilmu

Walginto, Bimo, 1990, Bimbingan dan Penyuluhan di Sekolah, Yogyakarta Yayasan Fak. Uharani, 1993, Metodolohi Openelitian Agama Islam, Jakarta: Bumi Aksara 
